\title{
Above- and below-ground vertebrate herbivory may each favour a different subordinate species in an aquatic plant community
}

\author{
Bert Hidding • Bart A. Nolet $\cdot$ Thijs de Boer \\ Peter P. de Vries • Marcel Klaassen
}

Received: 9 November 2008 / Accepted: 11 August 2009 / Published online: 10 September 2009

(C) The Author(s) 2009. This article is published with open access at Springerlink.com

\begin{abstract}
At least two distinct trade-offs are thought to facilitate higher diversity in productive plant communities under herbivory. Higher investment in defence and enhanced colonization potential may both correlate with decreased competitive ability in plants. Herbivory may thus promote coexistence of plant species exhibiting divergent life history strategies. How different seasonally tied herbivore assemblages simultaneously affect plant community composition and diversity is, however, largely unknown. Two contrasting types of herbivory can be distinguished in the aquatic vegetation of the shallow lake Lauwersmeer. In summer, predominantly above-ground tissues are eaten, whereas in winter, waterfowl forage on below-ground plant propagules. In a 4-year exclosure study we experimentally separated above-ground herbivory by waterfowl and large fish in summer from below-ground herbivory by Bewick's swans in winter. We measured the individual and combined effects of both herbivory periods on the composition of the three-species aquatic plant community. Herbivory effect sizes varied considerably from year to year. In 2 years herbivore exclusion in summer reinforced dominance of Potamogeton pectinatus with a concomitant decrease in Potamogeton pusillus, whereas no strong, unequivocal effect was observed in the other 2 years. Winter exclusion, on the other hand, had a negative effect on Zannichellia palustris, but the effect size differed considerably between
\end{abstract}

Communicated by Scott Collins.

B. Hidding $(\bowtie) \cdot$ B. A. Nolet · T. de Boer · P. P. de Vries .

M. Klaassen

Department of Plant-Animal Interactions,

Centre for Limnology, Netherlands Institute of Ecology,

Rijksstraatweg 6,3631 AC Nieuwersluis, The Netherlands

e-mail: b.hidding@nioo.knaw.nl years. We suggest that the colonization ability of $Z$. palustris may have enabled this species to be more abundant after reduction of $P$. pectinatus tuber densities by swans. Evenness decreased due to herbivore exclusion in summer. We conclude that seasonally tied above- and below-ground herbivory may each stimulate different components of a macrophyte community as they each favoured a different subordinate plant species.

Keywords Aquatic macrophytes - Waterfowl - Tubers · Competition colonization trade-off $\cdot$ Bare patch formation

\section{Introduction}

The effect of herbivores on plant community diversity can have one of two outcomes. Generalist herbivores have been associated with decreased plant diversity in settings characterised by low productivity, where few species are tolerant or resistant to consumption (Olff and Ritchie 1998; Proulx and Mazumder 1998; Bakker et al. 2006). In contrast, herbivory has been found to positively affect diversity in productive grassland systems (Summerhayes 1941; Noy-Meir et al. 1989; Bakker et al. 2006), but also in disparate marine habitats such as the rocky intertidal (Lubchenco 1978).

Herbivore-mediated increases in plant diversity have been explained in terms of two trade-offs. Firstly, a tradeoff may exist between plant defence and competitive ability (Lubchenco 1978; Gleeson and Wilson 1986), allowing both defensive and more palatable competitive species to coexist under herbivory. A second trade-off that may promote diversity is a shift in the balance between colonization and mortality (Olff and Ritchie 1998). This trade-off may come into effect when herbivory results in open patches. A negative correlation between a plant's ability to compete 
for resources and its capacity to colonize these open patches may allow a great number of species to coexist (Tilman 1994).

Few studies have addressed the formation of bare patches by herbivores explicitly; however, it seems that their formation depends, at least in part, on the identity of the herbivore (Olff and Ritchie 1998; Bakker et al. 2006). In grassland systems, rabbits (Bakker and Olff 2003), prairie dogs (Coppock et al. 1983), picas (Bagchi et al. 2006) and bisons (Collins and Barber 1985) were all reported to promote species diversity through the creation of bare patches. Collins and Barber (1985) also suspected additive diversity effects of grazing and bare patch formation through bison wallowing. For such animals however, grazing and wallowing are unavoidably entangled.

Freshwater wetlands provide an excellent opportunity to investigate the separate effects of bare patch formation and above-ground grazing. Many of these systems in temperate climates experience foraging on above-ground biomass by waterfowl (Jupp and Spence 1977; Lauridsen et al. 1993; Søndergaard et al. 1996; Van Donk and Otte 1996) and fish (Prejs 1984; Van Donk and Otte 1996) during the warmer months. In winter, however, after die-off of the aboveground plant parts, tubers and roots of aquatic plants are consumed by migratory waterfowl (Anderson and Low 1976; Beekman et al. 1991; Nolet et al. 2001; Sponberg and Lodge 2005). These birds, most notably swans and canvasbacks, may effectively deplete entire patches, as propagules and with them individual ramets are consumed. This results in a mosaic of patches varying widely in the density of tubers remaining (Klaassen and Nolet 2008). Conversely, summer grazing frequently results in stem breakage (Schutten et al. 2005), leaving individual plants damaged, but alive. These different modes of herbivory may each affect the suitability of species traits along different trade-offs, potentially resulting in additive effects in terms of species composition.

To date, studies on the effects of vertebrate herbivory on community composition in aquatic systems have focused on waterfowl herbivory on above-ground tissues. These studies report a reduction in the seemingly most palatable macrophyte species in control plots relative to exclosure plots, and no effect or an increase in less-preferred species inside the exclosures (Van Donk and Otte 1996; Santamaria 2002; Rodriguez-Villafane et al. 2007; Van de Haterd and Ter Heerdt 2007). In contrast, community composition effects of below-ground herbivory in shallow lakes have seldom been studied (but see LaMontagne et al. 2003), although remarkable and counterintuitive effects of Bewick's swans foraging on fennel pondweed (Potamogeton pectinatus) tubers were found in Lake Krankesjön in Sweden (Sandsten and Klaassen 2008). While the $P$. pectinatus tubers were most eaten by swans, competing perfoliate pondweed (Potamogeton perfoliatus) was virtually wiped out by the sediment disturbances caused by the swans. As a result, the relationship between Bewick's swans and fennel pondweed represents a case of ecological mutualism (Sandsten and Klaassen 2008).

The influence of below-ground herbivory by Bewick's swans may be such that antagonistic coevolution has led to ecological mutualism (De Mazancourt et al. 2001). On the other hand, as herbivory on below-ground propagules results in bare patches, good colonizers may profit at the expense of dispersal-limited dominant resource competitors, resulting in an increase in plant diversity. In parallel, herbivory by waterfowl and fish on above-ground tissues of aquatic macrophytes may compare to the positive diversity effect of herbivores as observed in grasslands and rocky intertidal communities, i.e. to the disadvantage of the palatable, productive species.

In a 4-year exclosure study, we combined exclusion of above-ground herbivores in summer (ducks, coots, mute swans and large fish) and below-ground foraging by Bewick's swans in winter in a full factorial design. We thereby simultaneously considered the possible changes that both above-ground and below-ground herbivory may have on the species composition and evenness of a macrophyte community over multiple years. We considered the evenness component of diversity since changes in species number are trivial in this species-poor community. We tested the following hypotheses: (1a) Bewick's swans facilitated growth of their food source fennel pondweed by damaging and burying turions and seeds of competitors (ecological mutualism), or alternatively, (1b) foraging Bewick's swans promoted community evenness by alleviating interspecific competition through local removal of $P$. pectinatus tubers, which created opportunities for colonizers; (2) selective foraging of mute swans, coots and ducks on the competitively dominant macrophyte species in summer facilitated subordinates and hence endorsed evenness.

\section{Materials and methods}

\section{Experimental site}

Exclosure experiments were carried out in the Babbelaar, a branch of the shallow lake Lauwersmeer (The Netherlands), that is closed to the public $(2,100$ ha, $\left.53^{\circ} 22^{\prime} \mathrm{N}, 06^{\circ} 13^{\prime} \mathrm{E}\right)$. The lake is eutrophic to hypertrophic with a mean concentration of total $\mathrm{N}$ of $3.4 \mathrm{mg}^{-1}$ and total $\mathrm{P}$ of $0.28 \mathrm{mg} \mathrm{l}^{-1}$ (mean of monthly measurements made October 2003-October 2007 covering the experimental period; data provided by the Noorderzijlvest water board). 
The Lauwersmeer is a former bay of the Wadden Sea that has become a freshwater lake since its embankment in 1969. The water level of the lake is strictly managed by means of sluice drainage to achieve the target level $(-93 \mathrm{~cm}$ relative to the Amsterdam ordnance datum). From the early 1970s onwards the lake was gradually colonised by fennel pondweed (Potamogeton pectinatus L.). At the time the reported study started, fennel pondweed could be found along the whole Lauwersmeer shoreline. In the Babbelaar, $P$. pectinatus dominates, yet it is likely to be more dispersal limited than the two other submersed macrophyte species that were present, as it propagates mostly by means of subterranean tubers positioned at relatively short distances from the maternal plant. Lesser pondweed (Potamogeton pusillus L.), propagates mostly through turions formed above ground (Barrat-Segretain and Bornette 2000), whereas horned pondweed (Zannichellia palustris L.) reproduces mainly through seeds (Van Vierssen 1982).

Since the mid 1970s, high numbers of Bewick's swans annually visit the lake on their autumn migration (Prop and van Eerden 1981). The birds usually arrive in the Lauwersmeer area in October and forage on the tubers of fennel pondweed (Beekman et al. 1991; Nolet et al. 2001). The total time spent on tuber foraging in the Lauwersmeer is typically short, and numbers quickly drop after 2-4 weeks of massive swan presence as a fixed giving-up density of pondweed tubers is attained (Nolet et al. 2006). In the autumns (2003-2006) preceding above-ground sampling in summer, 4,000, 5,500, 2,800 and 1,200 swan-days (= the sum of daily swan counts) were recorded in the Babbelaar, respectively (Nolet et al. 2006, A. Gyimesi and B. A. Nolet, unpublished data).

In summer, the macrophyte beds in the Lauwersmeer are exploited mainly by coot (Fulica atra L.), mallard (Anas platyrhynchos L.), gadwall (Anas strepera L.), common teal (Anas crecca L.) and mute swan (Cygnus olor Gmelin). In summer, birds were counted on a monthly basis covering the whole Lauwersmeer [data from the Staatsbosbeheer (state forestry service)]. Bird numbers increased from May to August in a similar way in each year of the study. Numbers steadily increased from around 1,200 coots and ducks in May numbers to $\pm 17,000$ in August (Fig. 1). Mute swan numbers were more stable over these months, fluctuating between 400 and 1,100 individuals. Fish community data had been collected in 2000 (Kroes and Riemersma 2001). Bream (Abramis brama L.) was the most abundant fish in biomass but this species is not herbivorous. Roach (Rutilus rutilus L.) and carp [Cyprinus carpio (L.)] were the most abundant facultative herbivores. The density of roach was estimated at $22 \mathrm{~kg} \mathrm{ha}^{-1}$. Carp was estimated at $58 \mathrm{~kg} \mathrm{ha}^{-1}$ while rudd [Scardinius erythrophthalmus (L.)] density was low at $1.5 \mathrm{~kg} \mathrm{ha}^{-1}$ (Kroes and Riemersma 2001).
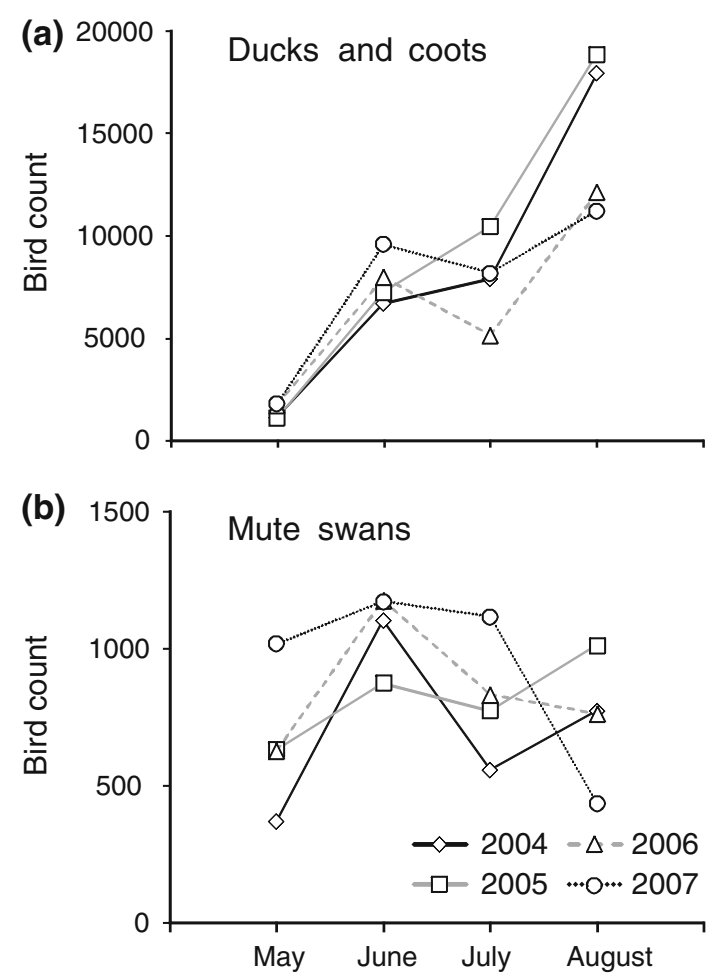

Fig. 1 Number of birds observed each month over the summer on the Lauwersmeer, the Netherlands: a ducks and coots, b mute swans (Cygnus olor Gmelin). Ducks and coots include coots (Fulica atra L.), gadwalls (Anas strepera L.), mallards (Anas platyrhynchos L.), and common teal (Anas crecca L.). Data for swans are reported separately because they are more than an order of magnitude heavier than ducks and coots. Note scales are different on y-axes

\section{Experimental design}

In early October 2003, prior to the arrival of Bewick's swans, eight $12 \times 12-\mathrm{m}$ exclosure blocks were established in the Babbelaar (Fig. 2). Exclosure blocks were divided into four $6 \times 6-\mathrm{m}$ plots, each receiving one of four treatments: a summer exclosure preventing the consumption of above-ground parts by birds (s), a winter exclosure preventing tuber-digging waterfowl from disrupting the sediment (w), a year-round exclosure, which was a combination of both treatments $(\mathrm{s}+\mathrm{w})$, and a control plot $(\mathrm{c})$, which was open year round (Fig. 2). Treatments were randomly assigned to the four plots within a block. For the summer treatment a $6 \times 6-\mathrm{m}$ cage was made, constructed of wooden poles and mesh wire (mesh size $5 \mathrm{~cm}$ ). The cages were topped with bird netting. Each year, the cages were erected in March and removed at the end of September. As cages in winter would possibly be vulnerable to forces exerted by ice, the winter treatment instead consisted of mesh wire placed on the sediment surface. The mesh wire was kept in place with short bamboo sticks from late September until March. We established two sets of four blocks, 


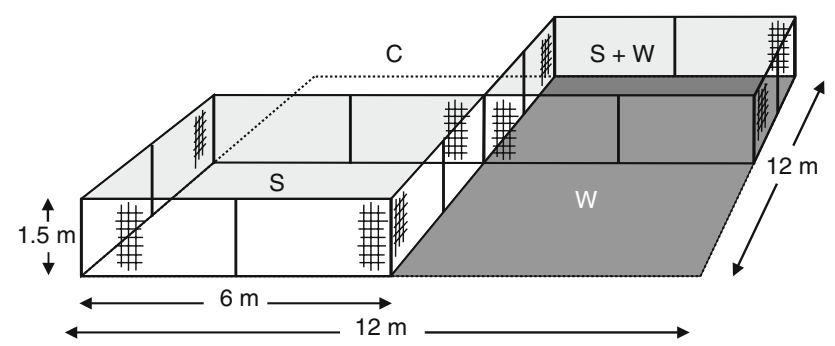

Fig. 2 Diagram of the experimental treatment layout established in the Lauwersmeer. The two treatments indicated by shading were separated in time, and treatment plots were randomly assigned within blocks. The summer treatment (light grey) ran from March until September and the winter treatment (dark grey) from September until March. $c$ Control plot, $s$ summer exclosure, $w$ winter exclosure, $s+w$ year-round exclosure

which were $180 \mathrm{~m}$ apart. Within each set of blocks the distance between the centres of the blocks was $40 \mathrm{~m}$. A slight gradient in water depth existed with decreasing water depth from block 1 ( $62 \pm 2 \mathrm{~cm}$ SD relative to target level) to block 8 ( $35 \pm 2 \mathrm{~cm} \mathrm{SD;} \mathrm{Hidding} \mathrm{et} \mathrm{al.} \mathrm{2009).}$

\section{Sampling}

All sampling was done inside an area of $4.5 \times 4.5 \mathrm{~m}$ within the $6 \times 6-\mathrm{m}$ treatment plots in order to minimize edge effects. This area in turn was divided into 36 squares of $75 \times 75 \mathrm{~cm}$. Above-ground material to be sorted to species level was sampled in mid June and 5 weeks later, in mid July. On each of these occasions one of the 36 squares was sampled. Assignment of sampling squares to sampling occasions was done at random, with the restriction that each sampling square was visited only once. Material was sampled by placing a $50-\mathrm{cm}$-diameter core over the vegetation. Plants were then harvested by hand at the sediment surface and sorted to species level in the laboratory. The samples were dried at $60^{\circ} \mathrm{C}$ for $72 \mathrm{~h}$ and subsequently weighed. The density of fennel pondweed tubers was assessed both at the end of September and in March by collecting twelve 7-cm-diameter, 35-cm-deep cores of sediment, more or less evenly spaced inside each treatment plot. The cores were sieved in the field at mesh size $3 \mathrm{~mm}$. Tubers were pooled for each plot, dried, and weighed.

\section{Statistical analysis}

The effect of exclosure treatments and covariates on species above-ground biomass, species proportions and evenness was assessed in a linear mixed effect model using the nlme package in R (Pinheiro and Bates 2000). Biomass data were normalised using a cube-root transformation, whereas species proportions were arcsine transformed. Evenness was estimated using the (untransformed) Shannon evenness index $\left[H^{\prime} / \ln (S)\right.$; Shannon and Weaver 1963; Pielou 1966]. In the experimental design, winter treatment, summer treatment and year were fixed factors. The factor month of sampling was nested within year. This was done since sampling dates among years may correspond to different stages in the plant's phenology, making months unique representatives of a given year. Secondly, months represent repetitive measurements at a different scale than years. Block was a random factor within which summer exclusion, winter exclusion and year were crossed. As the two covariates block depth and sediment silt content were not independent (simple regression $F_{1,30}=7.95, P<0.01$ ) with sandier sediment in the shallower blocks, a composite abiotic parameter was calculated using a reduced major axis regression. Three different models were constructed containing the three different covariates and their interactions with the fixed categorical factors. The covariates were either water depth, sediment silt content or a composite abiotic variable. The log-likelihood of the different models was calculated under fixed $d f$ and the model with the highest log-likelihood was chosen for further analysis, in effect including a single covariate. The number of relevant interactions was estimated by fitting the data with a full model, one with threeway interactions, a model with two-way interactions and a model without interactions using maximum likelihood (ML) estimation. A likelihood ratio test at $\alpha=0.05$ was used to decide whether including higher interaction levels returned a better fit, as is appropriate for hierarchically nested models (Hilborn and Mangel 1997). ANOVAs were then applied to the selected model including block as random factor using a restricted ML estimation method. After determination of the interaction levels the significance of the random factor block was determined using a likelihood ratio test comparing the fit of the models with block as random factor and models without the variable block. The significance threshold $(\alpha)$ was Bonferroni adjusted for the $F$-tests by dividing 0.05 by 3 , the number of species simultaneously studied (new $\alpha=0.017$ ).

\section{Results}

Model selection yielded the best fit for models including water depth as covariate rather than sediment silt content or a composite abiotic parameter. This was true for all response variables. Also, in all cases only two-way interactions were significant according to likelihood ratio tests on interaction levels. The predictor variable year was always highly significant (Table 1) indicating variability among years for above-ground plant biomass of the three considered species (Fig. 3). In addition, the three plant species responded differently within years resulting in variable proportional differences between species (Fig. 4). However, 


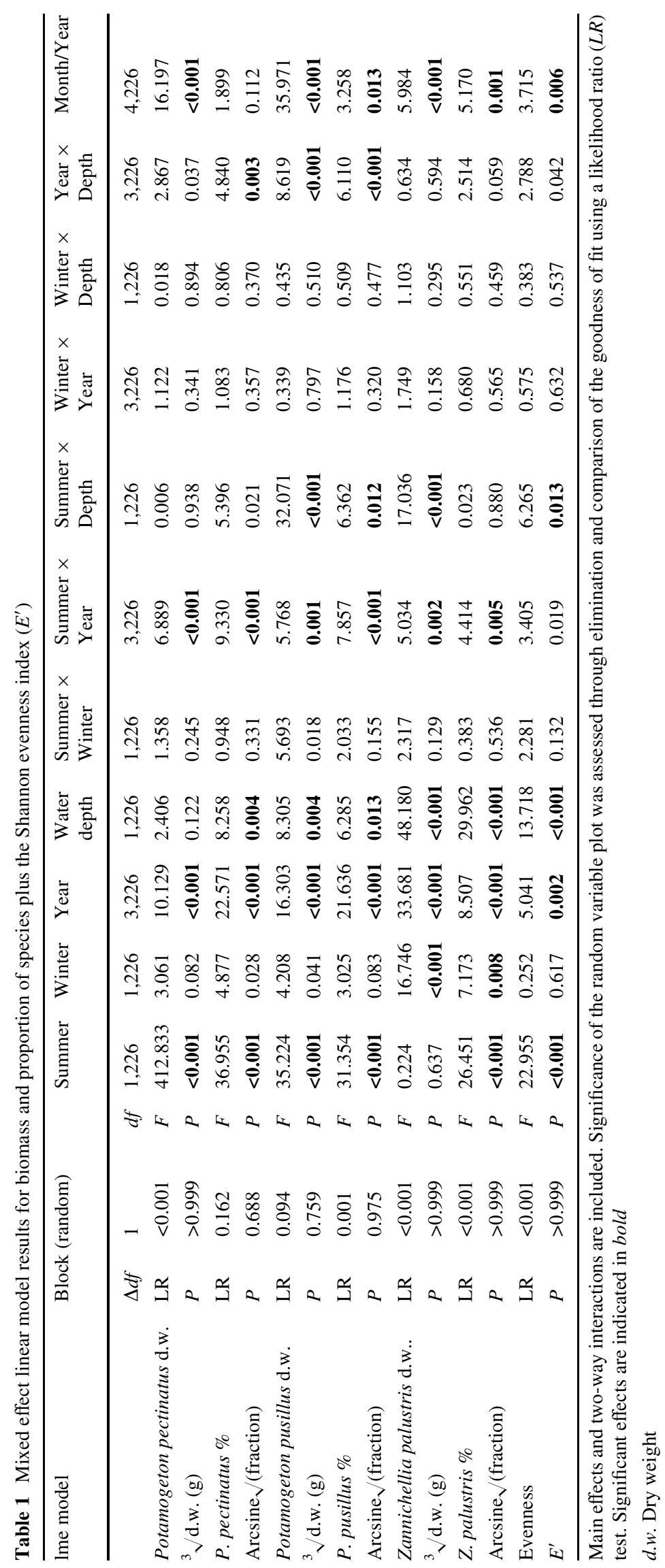




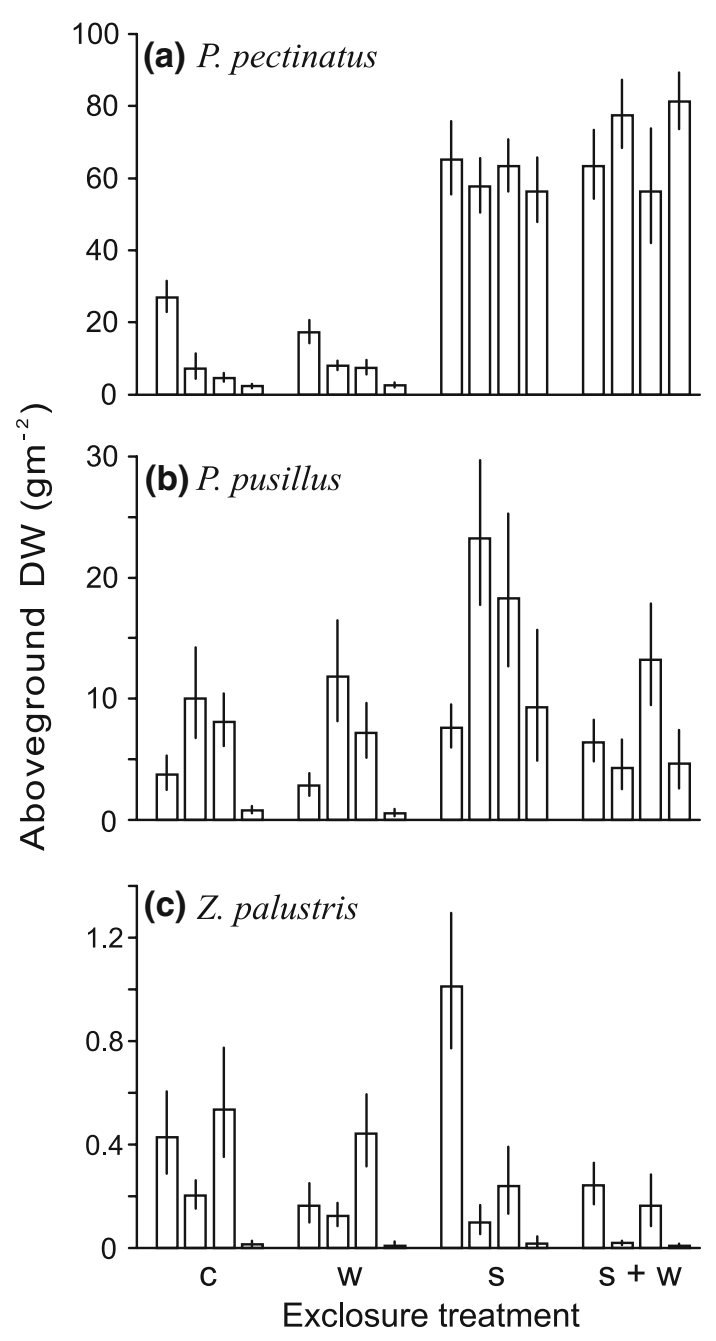

Fig. 3 Above-ground biomass (mean $\pm \mathrm{SE}$ ) in response to the experimental treatments for a Potamogeton pectinatus, $\mathbf{b}$ Potamogeton pusillus and c Zannichellia palustris. Data for each year (2004, 2005, 2006 and 2007) are presented chronologically from left to right within each treatment. Error bars based on mean squares of the residuals from a mixed effect model (winter, summer and year as fixed factors and plot as random factor) fitted to the July cube-root-transformed species biomass data ( $n=8$ blocks). Note scales are different on $y$-axes. For abbreviations, see Fig. 2

this yearly variation was not independent of the summer treatment in any of the cases. All response variables revealed a significant or marginally significant year $\times$ summer treatment interaction. Water depth significantly affected biomass and proportions of all species except in the case of $P$. pectinatus biomass. Block was not significant in any of the cases. Also the factor month was significant for all response variables except $P$. pectinatus proportions.

Above-ground biomass of $P$. pectinatus increased as a result of the summer treatment (s, s + w; Table 1; Fig. 3a) and the increase varied over the years (significant summer $\times$ year interaction). Biomass of $P$. pectinatus inside and outside summer treatment plots differed roughly by 1 order of magnitude. No significant block effect was observed for this species (Table 1; Fig. 5a). The proportion of $P$. pectinatus in the community was higher in the summer exclosed plots in 2005 and $2006(\mathrm{~s}, \mathrm{w}+\mathrm{s})$ than in the summer open plots $(\mathrm{c}, \mathrm{w})$. While this effect was much more subtle or absent in 2004 and 2007 (Fig. 4), there was still an overall significant summer treatment effect and summer $\times$ year interaction. In contrast, exclusion of belowground herbivory by swans in winter $(\mathrm{w}, \mathrm{s}+\mathrm{w})$ did not result in any significant effect on $P$. pectinatus plant biomass and only a marginally significant effect on the proportion of $P$. pectinatus (Table 1). Consumption of fennel pondweed tubers by swans had been considerable nonetheless, with an average reduction of tuber biomass from September to March of $75 \%$ inside summer exclosures (s), $66 \%$ in control plots (c) against $12 \%$ in winter exclosures (w) and 34\% in year-round exclosures ( $\mathrm{s}+\mathrm{w}$ ) (cf. Hidding et al. 2009).

$P$. pusillus reacted differently to the summer treatment depending on whether the absolute or relative scale was considered. Above-ground biomass was highest in the summer exclosed plots (s) whereas no pronounced effect was visible in all the other treatments (Fig. 3b). Hence, in addition to a significant summer exclusion effect, the interaction between the summer and winter treatments was marginally significant (Table 1). P. pusillus biomass reached higher densities in the shallower blocks (blocks 5-8). The interactions between water depth and the summer treatment and between year and water depth were also significant (Table 1; Fig. 5b). The fraction of $P$. pusillus, however, decreased as an effect of the summer treatment $(\mathrm{s}, \mathrm{s}+\mathrm{w})$ since the increase in $P$. pectinatus biomass was significantly more pronounced here. For the proportion of $P$. pusillus, the summer $\times$ year interaction was significant whereas the winter treatment $(\mathrm{w}, \mathrm{s}+\mathrm{w})$ was not.

Z. palustris occurred rarely throughout the experimental period, with a mean of around $0.15 \mathrm{~g} \mathrm{~m}^{-2}$ dry weight (d.w.) in c plots. A strong effect of water depth was observed for this species, both in terms of biomass and proportion of the total (Table 1; Fig. 5c), with outliers of about $5 \mathrm{~g} \mathrm{~m}^{-2}$ d.w. in the shallower blocks 5-8. Also, interactions between summer treatment and water depth and summer treatment and year were significant for plant biomass (Table 1), whereas only the latter was significant for the species proportion. We found no significant effect of the summer treatment $(\mathrm{s}, \mathrm{s}+\mathrm{w})$ on $Z$. palustris biomass (Table 1), independent of year or water depth. Summer treatment had an effect on the Z. palustris proportion in the species pool, which is due to the increase in the other species. Winter treatment $(w, s+w)$ had a negative impact both on biomass and proportion of Z. palustris (Table 1, Fig. 3c). Z. palustris showed a significant response to the factor month but 
Fig. 4 The effect of the exclosure treatments on species composition. Mean proportion of the biomass of each species calculated from pooled arcsinetransformed data for each year separately. Light grey

Proportion of $P$. pectinatus, dark grey proportion of $P$. pusillus, white proportion of Z. palustris. Error bars denoting 95\% confidence intervals are given to the left of each treatment for $P$. pectinatus, and right for $P$. pusillus. For abbreviations, see Fig. 2

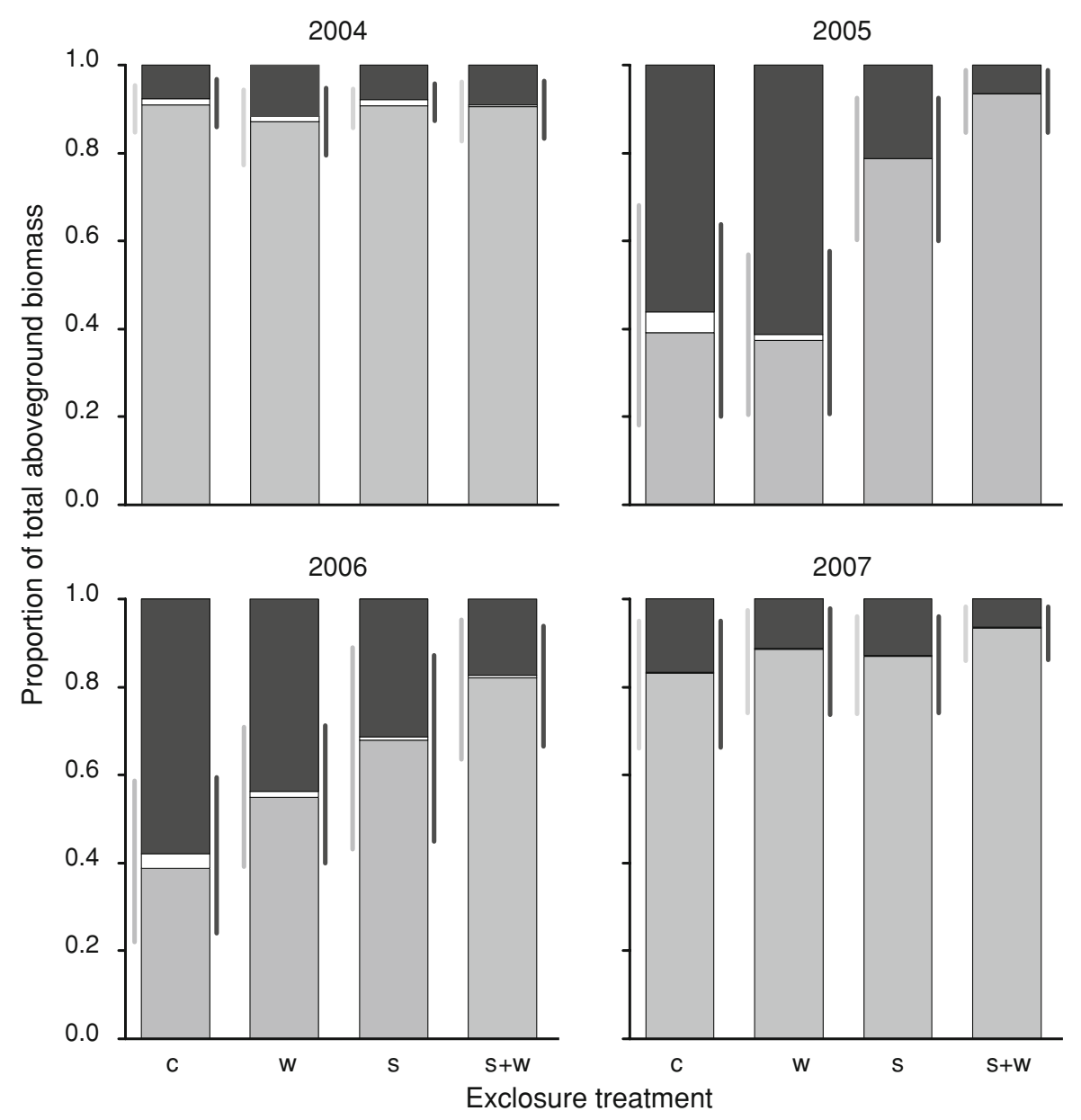

no consistent seasonal pattern was observed for this species.

The Shannon evenness index $(J)$ reacted negatively to the exclusion of summer herbivory but showed no significant response to the winter treatment (Table 1). The interaction between year and summer treatment was marginally significant. In our case, differences in species number were negligible such that $J$ was qualitatively similar to the Shannon diversity index $\left(J=H^{\prime} / \ln (S)\right)$. In addition, $H^{\prime}$ followed more or less the pattern detected in the two Potamogeton species. Evenness between $P$. pusillus and $P$. pectinatus was higher in the summer open plots $(c, w)$ than in the exclosures. Because of the tiny fraction of $Z$. palustris in the community, the Shannon index was barely reflective of changes due to treatment in this species.

\section{Discussion}

We found a strong positive effect of summer herbivore exclusion on biomass of Potamogeton pectinatus and a reinforcement of its dominance in the macrophyte community in 2005 and 2006. In 2004 and 2007, the biomass of
$P$. pectinatus was positively affected by exclusion of summer herbivores but dominated the species composition in all treatments. Potamogeton pusillus reached higher biomass inside summer exclosures (s) but decreased in relative terms, mostly so in 2005 and 2006 . Vertebrate herbivory in summer thus enhanced evenness at our study site in 2 out of 4 years by reducing the dominant plant species. In winter exclosed plots $(\mathrm{w}, \mathrm{w}+\mathrm{s})$, both the biomass and relative contribution of Zannichellia palustris to the macrophyte community were lower, mostly so in 2004 and 2005, whereas the summer treatment only showed significant interactions with year and depth. Our data thus indicate that two functionally different and seasonally separated herbivore assemblages may each favour different subordinate macrophyte species, dependent upon year-to-year variation in growth of the separate species. Interactions between the summer treatment and year were observed for all species and $E^{\prime}$. In addition, an interaction between winter treatment and year was found for Z. palustris. Apparently, the effect of herbivores on species composition of macrophyte communities may vary strongly among years.

Interestingly, although herbivory exerts a strong topdown effect on the aquatic vegetation of the Lauwersmeer, 


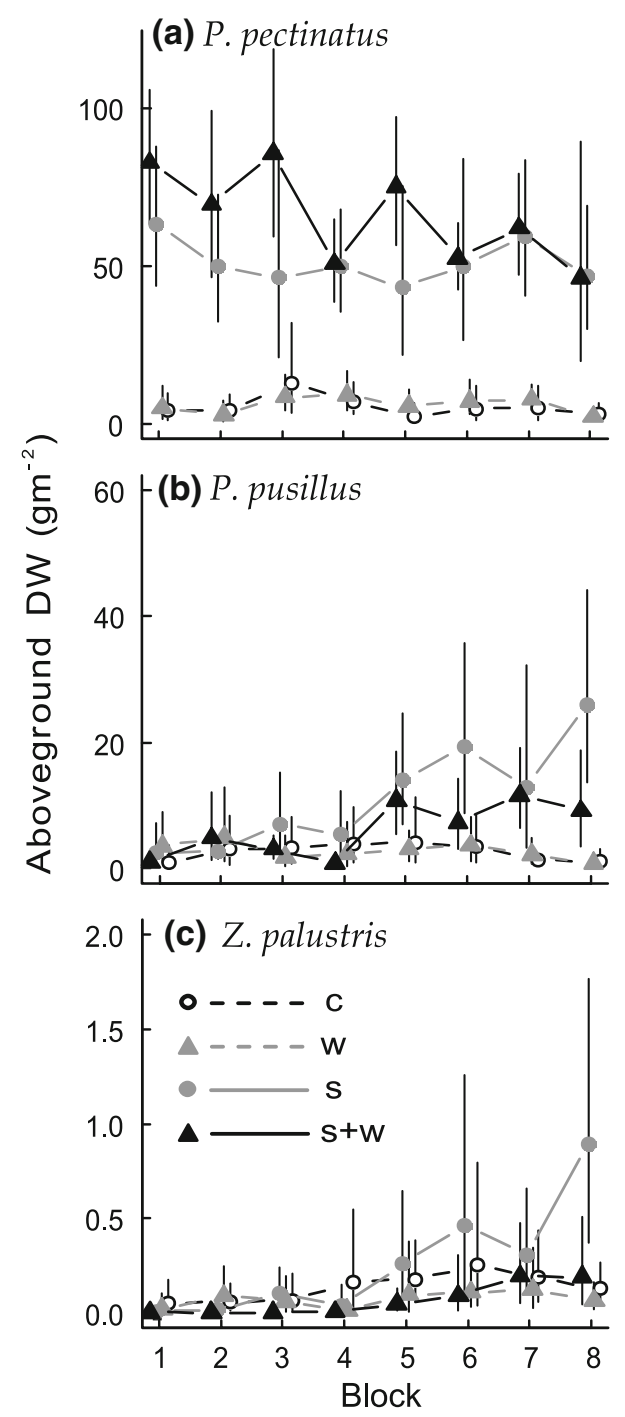

Fig. 5 Above-ground biomass for three aquatic plant species across blocks in each treatment. Values are mean $\pm \operatorname{SE}(n=4$ years) biomass with June and July data pooled. Water depth decreases from left to right. For abbreviations, see Fig. 2

we found no evidence for the idea that herbivores keep plant communities in an earlier successional stage, which would progress in the absence of herbivores. Although such observations are ubiquitous in some systems (e.g. Van Wijnen et al. 1999; Handa et al. 2002; Kuijper and Bakker 2005), in the aquatic plant community of the Lauwersmeer species composition appears to be reset every year.

The observed annual variability in biomass and species composition may be internally driven by density dependence in the propagule bank (Jonzén et al. 2002). However, this is not likely to be the case for fennel pondweed, since swans leave tuber densities at a relatively fixed threshold density below which foraging elsewhere becomes more profitable (Nolet et al. 2006). There was also a limited degree of variability in summer herbivory, apart from an unusually high number of mute swans in May 2007. Alternatively, interannual differences may depend on variables such as differences in the effectiveness of winter stratification (Van Wijk 1989), herbivory by snails in early spring (Elger et al. 2007) or competition between macrophytes and periphyton (Phillips et al. 1978). Although typical studies of vertebrate herbivory on aquatic macrophytes cover a single growing season (e.g. Santamaria 2002; Sandsten et al. 2005; Rodriguez-Villafane et al. 2007), quantitative predictions based on such studies may be problematic. Results obtained from exclosure studies in one year are not necessarily representative for all years, as interannual variation in recruitment success between species should be taken into account, also in the absence of successional patterns as in our study.

$P$. pectinatus is extensively foraged upon both in autumn as tubers by Bewick's swans and in summer as aboveground parts by waterfowl (Anderson and Low 1976; Santamaria 2002; Hilt 2006; this study) and possibly large fish, such as carp. Despite considerable reduction of tubers by Bewick's swans in winter, the effect on fennel pondweed biomass the next summer was limited. In the summer treatment plots $(s, s+w)$ however, strong growth of fennel pondweed reduced the proportional presence of $P$. pusillus when abundant in control plots (2005 and 2006). At present we do not know whether fennel pondweed is in fact a preferred food source over P. pusillus, but there are indications that this is not the case. In feeding trials quantifying the palatability of a range of aquatic plants using the pond snail Lymnaea stagnalis (L.) as a generalist herbivore, Elger et al. (2004) found no significant difference in palatability between $P$. pusillus and $P$. pectinatus. However, since $P$. pusillus distributes above-ground biomass more evenly across the water column, it may benefit from avian herbivores targeting only upper plant parts, which are more likely $P$. pectinatus. An additional advantage may then be the increased light availability just below the water surface. The proportional decrease in P. pusillus inside our exclosures may thus have resulted from the strong competitive abilities of $P$. pectinatus. In absolute terms there was an increase in $P$. pusillus inside summer exclosures indicating that it may nonetheless be consumed by herbivores in summer.

In the case of Z. palustris, higher densities were found in the shallower blocks (5-8). Interestingly, Z. palustris appears to perform better when exposed to Bewick's swans in winter, although the effect varies strongly among years. However, the plant might benefit from the grubbing activities of swans in autumn. This bioturbation may bring buried seeds from a previous more productive year for Z. palustris to the sediment surface, which can enhance recruitment. Although this is a tempting explanation, survival of Zannichellia spp. seeds over multiple years is thought to be 
limited (Bonis and Lepart 1994). A more likely explanation relates to the difference in colonization abilities. Unlike the two Potamogeton species, Zannichellia spp. produces many viable seeds (Van Vierssen 1982), which require only a short period of favourable conditions to germinate (Bonis et al. 1995). The seeds may easily be transported with water currents resulting in good colonization ability. Swans dig pits when foraging and are very efficient in reducing tuber densities within these pits (Klaassen and Nolet 2008). Through this sediment disturbance swans create bare patches that are largely free from competing fennel pondweed early in the growth season, allowing the annual Z. palustris to colonize. Mass effects (sensu Shmida and Wilson 1985) might then be responsible for higher densities later in the season.

Although effects were highly variable over the years, vertebrate herbivory may enhance evenness at our study site by reducing the dominant plant species through summer grazing, hence promoting the relative contribution of $P$. pusillus to the community. In addition, subordinate Z. palustris may benefit from tuber predation in winter because the competition-colonization trade-off under these circumstances may be to the advantage of colonizers. These positive herbivore effects appear conditional upon recruitment success of the subordinate species. The factors that are crucial to this recruitment effect remain largely unknown and pose an interesting subject of further study.

Our results are therefore partly in line with the positive effect of vertebrate herbivores on plant diversity in productive (eutrophic) grasslands (Olff and Ritchie 1998). Moreover, we suggest that above- and below-ground herbivory may each favour different constituents of diversity in this system. It is questionable however, whether positive diversity or evenness effects of herbivores apply to aquatic vegetation in general, since aquatic plants may experience profound competition from functionally and taxonomically dissimilar organisms; namely periphyton and phytoplankton. Avian herbivores may have an unfavourable impact on the vegetation under such conditions, possibly resulting in phytoplankton dominance (Scheffer et al. 1993). In eutrophic shallow systems $(<80 \mathrm{~cm}$ depth) such as the Lauwersmeer, macrophytes may on the other hand be fairly resistant to competition with algae, as these macrophytes often exhibit more or less floating canopies. Thus, depending on variability in recruitment success, above- and belowground avian herbivory may each facilitate different subordinate macrophyte species.

Acknowledgments We would like to thank Liesbeth Bakker, Paul Bodelier, Bob Brederveld, Anne Destin, Bas Dingemans, Olivier Duriez, Abel Gyimesi, Steffan Hahn, Bethany Hoye, Frida Keuper, Harry Korthals, Dick Kroon, Casper van Leeuwen, Mariska Nieuwenhuijsen, Anne Steenbergh, Koos Swart, Dirk-Jan Terlouw, and Marion Meima for helping to collect data during the study period and valuable discussions. We thank the Staatsbosbeheer for kindly providing bird count data and for allowing us to work in the Lauwersmeer nature reserve. Thanks to Liesbeth Bakker, Scott Collins and two anonymous reviewers for commenting on an earlier draft of this manuscript. Thanks to Jelena Pantel and Bethany Hoye for grammar and spelling corrections. This experiment complies with current laws in the Netherlands. This is Netherlands Institute of Ecology publication no. 4,556 and publication 518 of the Centre for Wetland Ecology.

Open Access This article is distributed under the terms of the Creative Commons Attribution Noncommercial License which permits any noncommercial use, distribution, and reproduction in any medium, provided the original author(s) and source are credited.

\section{References}

Anderson MG, Low JB (1976) Use of sago pondweed by waterfowl on the Delta Marsh, Manitoba. J Wildl Manage 40:233-242

Bagchi S, Namgail T, Ritchie ME (2006) Small mammalian herbivores as mediators of plant community dynamics in the high-altitude arid rangelands of Trans-Himalaya. Biol Conserv 127:438-442

Bakker ES, Olff H (2003) Impact of different-sized herbivores on recruitment opportunities for subordinate herbs in grasslands. J Veg Sci 14:465-474

Bakker ES, Ritchie ME, Olff H, Milchunas DG, Knops JMH (2006) Herbivore impact on grassland plant diversity depends on habitat productivity and herbivore size. Ecol Lett 9:780-788

Barrat-Segretain MH, Bornette G (2000) Regeneration and colonization abilities of aquatic plant fragments: effect of disturbance seasonality. Hydrobiologia 421:31-39

Beekman JH, van Eerden MR, Dirksen S (1991) Bewick's swans Cygnus columbianus bewickii utilising the changing resource of Potamogeton pectinatus during autumn in the Netherlands. Wildfowl Suppl 1:238-248

Bonis A, Lepart J (1994) Vertical structure of seed banks and the impact of depth of burial on recruitment in 2 temporary marshes. Vegetatio 112:127-139

Bonis A, Lepart J, Grillas P (1995) Seed bank dynamics and coexistence of annual macrophytes in a temporary and variable habitat. Oikos 74:81-92

Collins SL, Barber SC (1985) Effects of disturbance on diversity in mixed-grass prairie. Vegetatio 64:87-94

Coppock DL, Detling JK, Ellis JE, Dyer MI (1983) Plant-herbivore interactions in a North-American mixed-grass prairie. 1. Effects of black-tailed prairie dogs on intraseasonal above-ground plant biomass and nutrient dynamics and plant-species diversity. Oecologia 56:1-9

De Mazancourt C, Loreau M, Dieckmann U (2001) Can the evolution of plant defense lead to plant-herbivore mutualism? Am Nat 158:109-123

Elger A, Bornette G, Barrat-Segretain MH, Amoros C (2004) Disturbances as a structuring factor of plant palatability in aquatic communities. Ecology 85:304-311

Elger A, De Boer T, Hanley ME (2007) Invertebrate herbivory during the regeneration phase: experiments with a freshwater angiosperm. J Ecol 95:106-114

Gleeson SK, Wilson DS (1986) Equilibrium diet—optimal foraging and prey coexistence. Oikos 46:139-144

Handa IT, Harmsen R, Jefferies RL (2002) Patterns of vegetation change and the recovery potential of degraded areas in a coastal marsh system of the Hudson Bay lowlands. J Ecol 90:86-99

Hidding B, Nolet BA, De Boer T, De Vries PP, Klaassen M (2009) Compensatory growth in an aquatic plant mediates exploitative competition between seasonally tied herbivores. Ecology 90:1891-1899 
Hilborn R, Mangel M (1997) The ecological detective. Princeton university press, Princeton, New Jersey

Hilt S (2006) Recovery of Potamogeton pectinatus L. stands in a shallow eutrophic lake under extreme grazing pressure. Hydrobiologia 570:95-99

Jonzén N, Nolet BA, Santamaria L, Svensson MGE (2002) Seasonal herbivory and mortality compensation in a swan-pondweed system. Ecol Model 147:209-219

Jupp BP, Spence DHN (1977) Limitations of macrophytes in a eutrophic lake, Loch Leven. 2. Wave action, sediments and waterfowl grazing. J Ecol 65:431-446

Klaassen RHG, Nolet BA (2008) Persistence of spatial variance and spatial pattern in the abundance of a submerged plant. Ecology 89:2973-2979

Kroes MJ, Riemersma P (2001) Visserijkundig onderzoek Lauwersmeer, winter en zomer. In: Organisatie ter verbetering van de binnenvisserij, Nieuwegein

Kuijper DPJ, Bakker JP (2005) Top-down control of small herbivores on salt-marsh vegetation along a productivity gradient. Ecology 86:914-923

LaMontagne JM, Jackson LJ, Barclay RMR (2003) Compensatory growth responses of Potamogeton pectinatus to foraging by migrating trumpeter swans in spring stop over areas. Aquat Bot $76: 235-244$

Lauridsen TL, Jeppesen E, Andersen FO (1993) Colonization of submerged macrophytes in shallow fish manipulated Lake Vaengimpact of sediment composition and waterfowl grazing. Aquat Bot 46:1-15

Lubchenco J (1978) Plant species-diversity in a marine inter-tidal community-importance of herbivore food preference and algal competitive abilities. Am Nat 112:23-39

Nolet BA et al (2001) Spatial variation in tuber depletion by swans explained by differences in net intake rates. Ecology 82:16551667

Nolet BA, Gyimesi A, Klaassen RHG (2006) Prediction of bird-day carrying capacity on a staging site: a test of depletion models. J Anim Ecol 75:1285-1292

Noy-Meir I, Gutman M, Kaplan Y (1989) Responses of Mediterranean grassland plants to grazing and protection. J Ecol 77:290-310

Olff H, Ritchie ME (1998) Effects of herbivores on grassland plant diversity. Trends Ecol Evol 13:261-265

Phillips GL, Eminson D, Moss B (1978) Mechanism to account for macrophyte decline in progressively eutrophicated freshwaters. Aquat Bot 4:103-126

Pielou EC (1966) Shannons formula as a measure of specific diversity-its use and misuse. Am Nat 100:463-465

Pinheiro JC, Bates DM (2000) Mixed-effects models in S and S-PLUS. Springer Verlag, New York

Prejs A (1984) Herbivory by temperate freshwater fishes and its consequences. Environ Biol Fishes 10:281-296

Prop J, van Eerden MR (1981) Het voorkomen van trekvogels in het Lauwerszeegebied vanaf de afsluiting in 1969 tot en met 1978. Limosa 54:1-16
Proulx M, Mazumder A (1998) Reversal of grazing impact on plant species richness in nutrient-poor vs. nutrient-rich ecosystems. Ecology 79:2581-2592

Rodriguez-Villafane C, Becares E, Fernandez-Alaez M (2007) Waterfowl grazing effects on submerged macrophytes in a shallow Mediterranean lake. Aquat Bot 86:25-29

Sandsten H, Klaassen M (2008) Swan foraging shapes spatial distribution of two submerged plants, favouring the preferred prey species. Oecologia 156:569-576

Sandsten H, Beklioglu M, Ince O (2005) Effects of waterfowl, large fish and periphyton on the spring growth of Potamogeton pectinatus L. in Lake Mogan, Turkey. Hydrobiologia 537:239-248

Santamaria L (2002) Selective waterfowl herbivory affects species dominance in a submerged plant community. Arch Hydrobiol 153:353-365

Scheffer M, Bakema AH, Wortelboer FG (1993) Megaplant-a simulation-model of the dynamics of submerged plants. Aquat Bot 45:341-356

Schutten J, Dainty J, Davy AJ (2005) Root anchorage and its significance for submerged plants in shallow lakes. J Ecol 93:556-571

Shannon CE, Weaver W (1963) Mathematical theory of communication. University of Illinois press, Urbana

Shmida A, Wilson MV (1985) Biological determinants of species diversity. J Biogeogr 12:1-20

Søndergaard M, Bruun L, Lauridsen T, Jeppesen E, Madsen TV (1996) The impact of grazing waterfowl on submerged macrophytes: in situ experiments in a shallow eutrophic lake. Aquat Bot 53:73-84

Sponberg AF, Lodge DM (2005) Seasonal below-ground herbivory and a density refuge from waterfowl herbivory for Vallisneria americana. Ecology 86:2127-2134

Summerhayes VS (1941) The effect of voles (Microtus agrestis) on vegetation. J Ecol 29:14-48

Tilman D (1994) Competition and biodiversity in spatially structured habitats. Ecology 75:2-16

Van de Haterd RJW, Ter Heerdt GNJ (2007) Potential for the development of submerged macrophytes in eutrophicated shallow peaty lakes after restoration measures. Hydrobiologia 584:277290

Van Donk E, Otte A (1996) Effects of grazing by fish and waterfowl on the biomass and species composition of submerged macrophytes. Hydrobiologia 340:285-290

Van Vierssen W (1982) The ecology of communities dominated by Zannichellia taxa in Western Europe. 1. Characterization and autecology of the Zannichellia taxa. Aquat Bot 12:103-155

Van Wijk RJ (1989) Ecological studies on Potamogeton pectinatus L. 3. Reproductive strategies and germination ecology. Aquat Bot 33:271-299

Van Wijnen H, Van der Wal R, Bakker JP (1999) The impact of herbivores on nitrogen mineralization rate: consequences for saltmarsh succession. Oecologia 118:225-231 